\title{
ACTA MYCOLOGICA
}

Vol. 48 (1): $13-20$

2013

DOI: $10.5586 / \mathrm{am} .2013 .002$

\section{The unusual Gasteromycetes Lycogalopsis solmsii belongs to the gomphoid-phalloid group}

\author{
VINCENT DEMOULIN*, LUC CORNET, EMILIE DELBRUYÈRE \\ and DENIS BAURAIN
}

\begin{abstract}
Phylogénomique des Eucaryotes, Département des Sciences de la Vie, Institut de Botanique, B22 Université de Liège, B-4000 Liège, *corresponding author: V.Demoulin@ulg.ac.be
\end{abstract}

Demoulin V., Cornet L., Delbruyère E., Baurain D.: The unusual Gasteromycetes Lycogalopsis solmsii belongs to the gomphoid-phalloid group. Acta Mycol. 48 (1): 13-20, 2013.

The rare tropical Gasteromycetes Lycogalopsis solmsii has been found twice at thirty years interval in the Singapore Botanic Gardens. From the most recent find a culture could be isolated, which allowed DNA extraction and sequencing of about $2000 \mathrm{bp}$ from the nuclear ribosomal DNA. Comparison to a large sample of Basidiomycetes was only possible for a part of the large ribosomal subunit, but clearly indicated affiliation to the gomphoid-phalloid group, without any relationship to Lycoperdales or Agaricales, as stated in the Dictionary of the Fungi.

Key words: Lycogalopsis, Gasteromycetes phylogeny, Lycoperdales, nucLSUrRNA

\section{INTRODUCTION}

Lycogalopsis solmsii was described by E. Fischer in 1886 as a new genus and species. Despite the detailed description and illustrations, typical of this great student of Gasteromycetes, the systematic position of this rare tropical fungus has remained unresolved until now.

In 1886 Fischer insisted on the very peculiar development of the fruitbody, starting from a stroma. He compared the fungus to Lycoperdaceae, Hymenogastraceae and Scleroderma, without proposing to place it in a family. In his great synthesis of 1933 for the Natürlichen Pflanzenfamilien he suggested possible placement in the Sclerodermataceae on account of the lacunose development of the gleba and simple peridium, but considered this still uncertain.

Patouillard, describing a second species, L. dussii from the Martinique (1902, the species is usually synonymised to $L$. solmsii) claimed the genus was close to Lycoperdon, a surprising opinion. This was however followed by Martin (1939) who formally placed the genus in Lycoperdaceae and gave one of the few descriptions of Lycogalopsis after the original one. 
Ainsworth and Bisby's Dictionary of the Fungi fluctuated in its classification: Sclerodermatales in the fourth (1954) edition and Lycoperdales in the sixth (Ainsworth, James and Hawksworth 1971). When one of us (V. D.) took up the redaction of the Gasteromycetes entries for the seventh edition (Hawksworth, Sutton and Ainsworth 1983), he kept this affiliation but added a question mark. For the eighth edition (Hawksworth et al. 1995) he intended to state "Gasteromycetes incertae sedis (Lycoperdales?)", but for undetermined reasons the printed text was "Lycoperdaceae". The ninth edition (Kirk et al. 2001) was prepared by a new team of which D. L. Hawksworth and V. Demoulin were not members. It retained the affiliation to Lycoperdaceae. In the present (tenth, Kirk et al. 2008) edition this is changed to Agaricaceae through the adoption of a pure cladistic classification which includes Lycoperdaceae in Agaricaceae.

V. Demoulin first collected Lycogalopsis solmsii in the Singapore Botanic Gardens the $9^{\text {th }}$ Dec. 1979 and since then has been convinced this was neither a Lycoperdales nor Sclerodermatales. He has worked in the Singapore Garden at multiple occasions since the days of the first collection and always tried without success to find Lycogalopsis again. Only after thirty years did he found it again during the same very wet period of the end of the year. Collections were made on $21 \mathrm{Nov}$. and $11^{\text {th }}$ Dec. 2009 and a culture could be grown. This allowed sequencing of about $2000 \mathrm{bp}$ of the nuclear ribosomal region in order to clarify the systematic affinity of the fungus.

\section{MATERIAL AND METHODS}

The following collections of Lycogalopsis solmsii are deposited in the herbarium of the University of Liège (LG, herbarium abbreviation are according to Holmgren, Holmgren and Barnett 1990):

Singapore, Botanic Gardens, on rotten woody debris near the exit of the Garden Jungle on Cluny road, 9.12.1979, V. Demoulin 5501, 5502, with slides 79-80/1/19, 20 (Fig. 1).

Singapore, Botanic Gardens, on wooden chips used as mulch around a young tree, near the Herbarium building, 21.11.2009, V. Demoulin 8078, slide 08-09/4/41, numerical pictures 259, 260; ibid. (same mycelium), V. Demoulin 8117, 11.12.2009, culture $\mathrm{n}^{\circ} 911$ (Fig. 2).

Those collections are duplicated in the herbarium of the Singapore Botanic Gardens (SING) and 5502 also in G and TUB.

Two collections from Gabon received from G. Gilles: Forêt de la Mondah N of Libreville, 29.5 and 26.6.1977.

A collection from Congo (Irangi, on dead rotten wood in primary rain forest, 5.1972, J. Rammeloo Z454 is deposited in the herbarium of the University of Gent (GENT) and was studied and published by V. Demoulin and D. M. Dring (1975).

The culture was isolated by placing a piece of the gleba of a young fruitbody on $2 \%$ malt agar. It was maintained on the same medium which suits the fungus well.

DNA extraction from culture 911 was according to Smith, Blanchette \& Newcombe (2004) that is on frozen then thawed material with the Qiagen Plant DNeasy Minikit (Qiagen, Valencia, CA). 


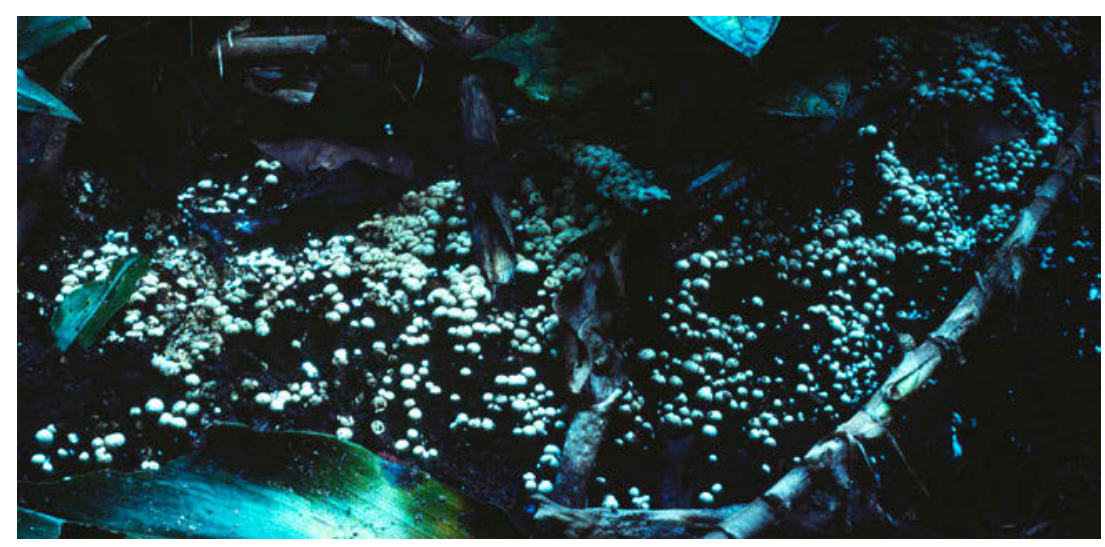

Fig. 1. Lycogalopsis solmsii, collection V. Demoulin 5502 in the Singapore Botanic Gardens, 9 Dec. 1979.

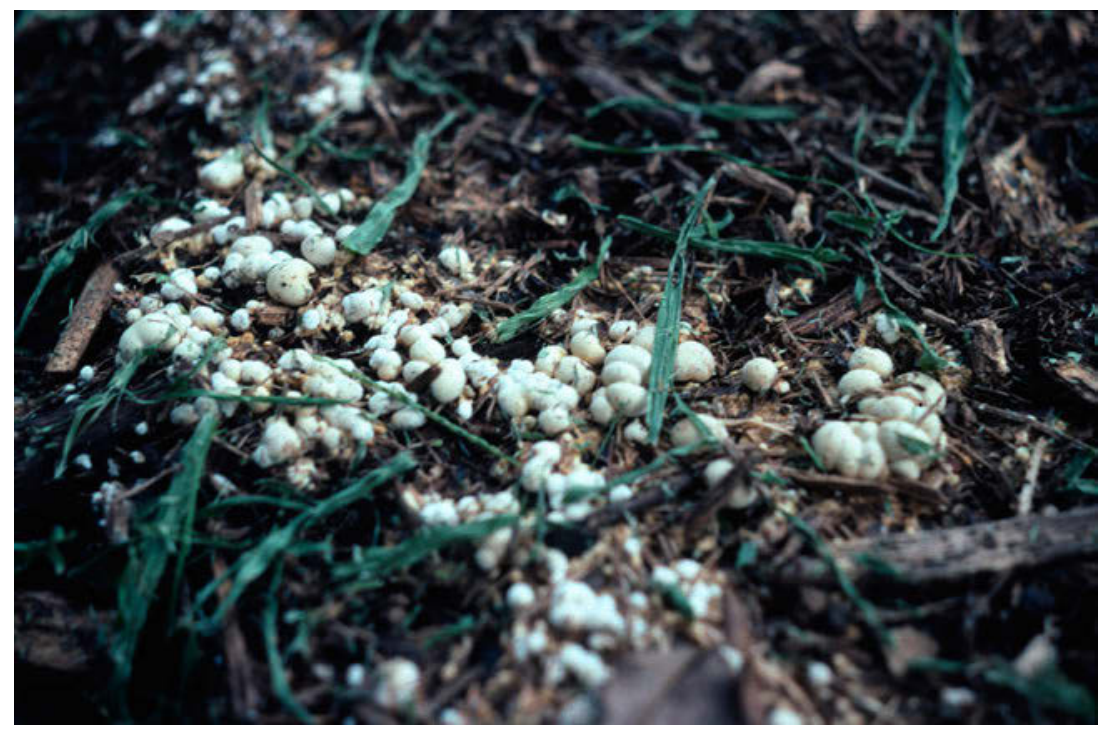

Fig. 2. Lycogalopsis solmsii, collection V. Demoulin 8078 in the Singapore Botanic Gardens, 21 Nov. 2009.

PCR amplification used three pairs of primers, 5.8S/LR21, LROR/LR7 and BMB-CR/LR1 following Vilgalys and Hester (1990) and Moncalvo, Wang \& Hseu (1995) for LROR and BMB-CR. This allows the amplification of about $2000 \mathrm{bp}$ from the end of the nuclear small ribosomal RNA subunit DNA to about the middle of the DNA of the large subunit (nucLSU).

Sequencing was performed by the company MacroGen Inc. (Seoul, South Korea). The sequence is deposited in GenBank under the accession KF017599.

For phylogenetic analysis, a 675-bp nucLSU fragment of Lycogalopsis solmsii was first aligned to a selection of homologous sequences taken from the SILVA database 
V. Demoulin et al.

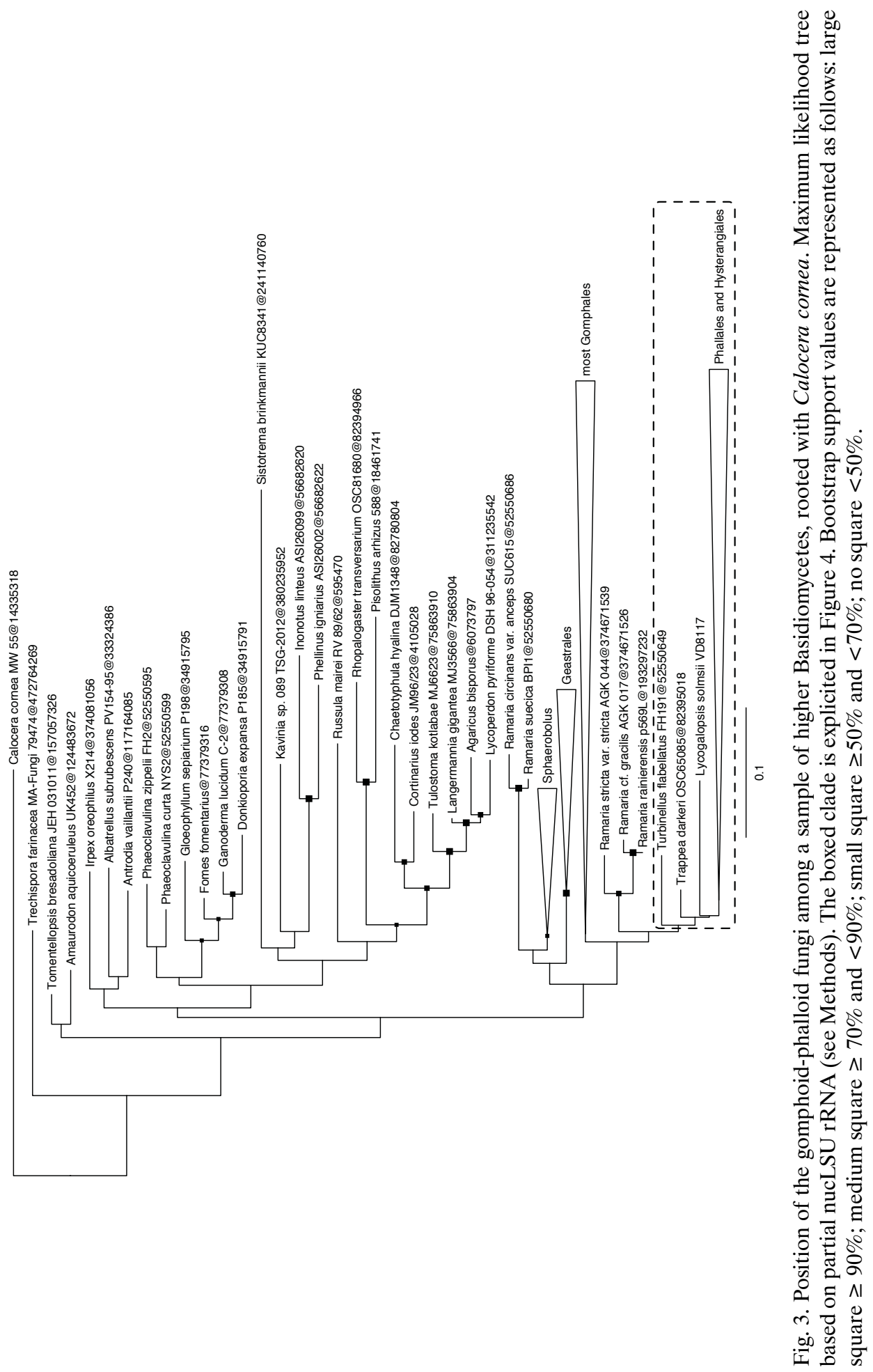




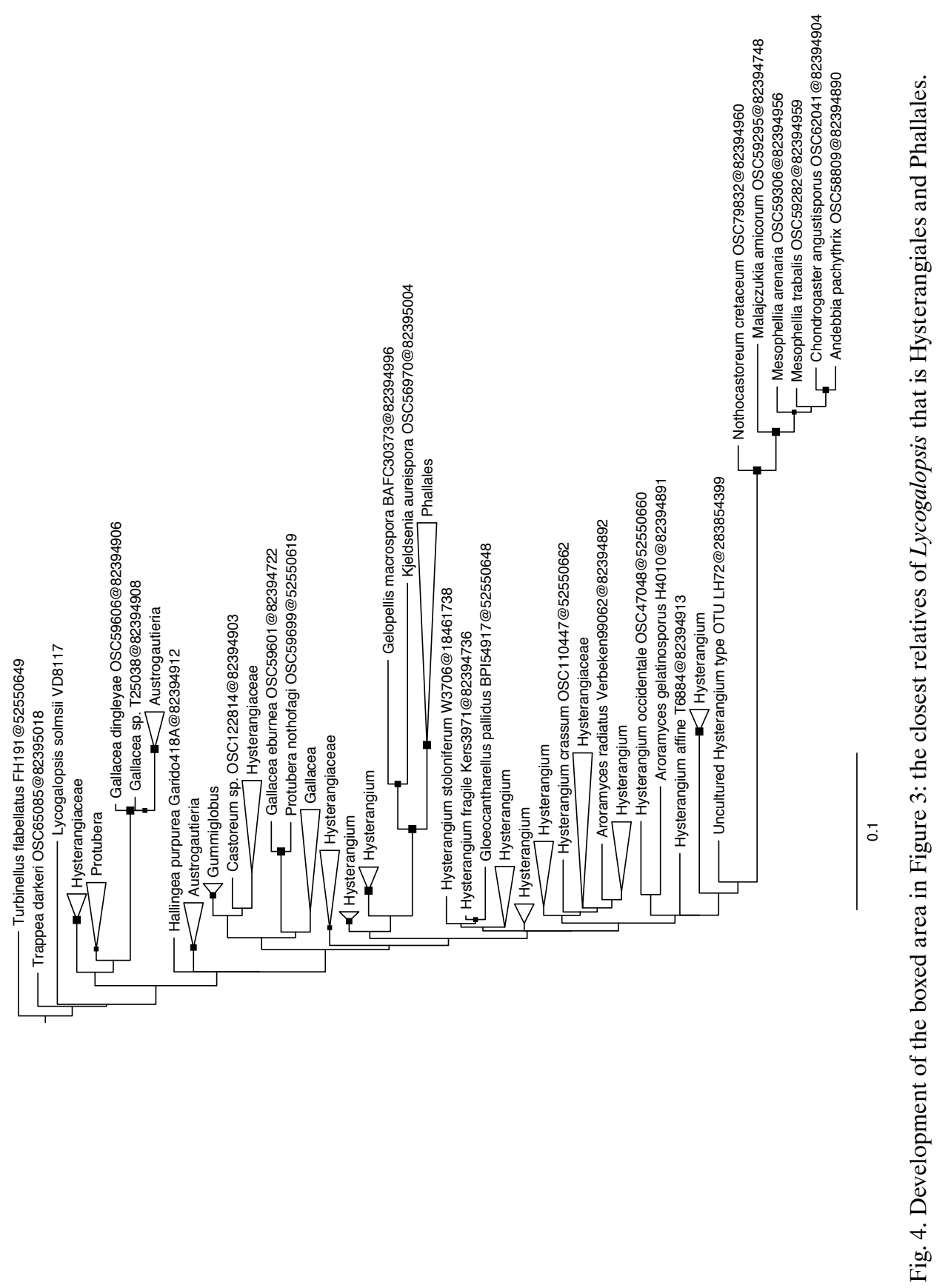


(Quast et al. 2013). The initial alignment was then iteratively enriched with GenBank sequences (Benson et al. 2013) selected from Giachini et al. (2010) and Hosaka et al. (2007) using a BLAST-based tool (BABA), which is part of the MUST software package (Philippe 1993). Additional sequences were subsequently identified in GenBank through a series of targeted BLAST searches (Altschul et al. 1997) limited to the Agaricomycetes (sensu NCBI Taxonomy; Federhen 2011). These were added to the alignment with BABA when they improved the sample diversity, as estimated from preliminary neighbour-joining trees computed with the MUST editor on the basis of MAFFT alignments (Katoh et al. 2005). The final alignment was manually refined using the MUST editor.

Of this master alignment, the positions due to insertions in less than $10 \%$ of the sequences were discarded using tools in Bio-MUST-Core (D. B., unpublished). Gblocks (Castresana 2000) was then used with loose parameters to further filter the least reliably aligned positions. Finally, the sequences having more than $50 \%$ missing characters were discarded, which yielded a dataset of 606 unambiguously aligned positions for 213 sequences.

The maximum likelihood tree was computed with PhyML (Guindon et al. 2010) using a GTR $+\Gamma_{4}$ model (Lanave et al. 1984; Yang 1993). The starting tree for the heuristic search was computed by parsimony and the search included both NNI (nearest-neighbour interchange) and SPR (subtree pruning and regrafting) topological moves. The bootstrap support (Felsenstein 1985) was estimated through the analysis of 100 pseudo-replicates, while the analysis of slightly different data sets (in terms of retained positions and/or species; data not shown) also indicated that the position of some taxa was unstable. The final tree was automatically annotated using Bio-MUST-Core and further arranged in FigTree (http://tree.bio.ed.ac.uk/software/ figtree/).

\section{RESULTS AND DISCUSSION}

It is unfortunate few Basidiomycetes sequences of the same length as ours exist in GenBank. It is only for the part (about $600 \mathrm{bp}$ at the beginning) of the nucLSU rRNA gene amplified by the primers LROR-LR3 that an important sample of taxa exists. We thus had to limit our comparisons to 606 unambiguously aligned positions present in a large sample of taxa. This comparison clearly pointed to a position in the gomphoid-phalloid clade and our best tree (Figs 3 and 4) places Lycogalopsis closer to Phallales and Hysterangiales than to Geastrales and Gomphales ss. Hosaka et al. (2007). The branch is however long, and there is no bootstrap support for its position. Indeed some modifications in the sampling of either characters or taxa might affect this position. We thus consider one has to wait for either sequences of more genes from Lycogalopsis, making it fully comparable to the taxa studied by Hosaka et al. (2007), or that more long ribosomal sequences, as we used, will be determined, before deciding on the ordinal assignation. One may note that our relative order of divergence of the four orders is not entirely similar to that of Hosaka et al. (2007) but neither is this entirely similar to that of Giachini et al. (2010) pointing out again the need for a larger sampling in taxa and genes. 
The possible affiliation of Lycogalopsis to the gomphoid-phalloid clade had been suggested by K. Hosaka in his 2005 thesis. No discussion of this correct intuition was however provided.

One may note some morphological features of Lycogalopsis are frequent in gasteroid members of the gomphoid-phalloid group. The elongated basidia with more than four apical spores are such a feature. Figure 1 of Martin (1939) is especially reminiscent of Geastrum basidia. In that genus one may also encounter a subiculum for exemple in G. schweinitzii (Berk. et Curt.) Zeller. In Lycogalopsis, this subiculum is best developed on firm wood and can be less evident on debris. The general appearance and the ecology are reminiscent of Phallobata alba Cunn. One can compare Figure 9 in Castellano and Beaver (1994) with our Figures 1 and 2, which are the first photographs of Lycogalopsis solmsii to be published. The greenish gelatinous gleba and smooth elongated spores are however quite different and more in line with usual Phallales and Hysterangiales.

One consequence of this study is that the present entry in the Dictionary of the Fungi (2008) is clearly misleading. The attribution to Agaricaceae (see in Fig. 3 the position of Agaricus and related Gasteromycetes like Lycoperdon) is one more example of problems caused by cladistic classification. Instead of placing organisms in a morphologically well-defined group, one uses a phylogenetic hypothesis that can be completely wrong. Further "widespread" is clearly inadequate.

If $\mathrm{V}$. Demoulin had to prepare again an entry for a Dictionary it would specify: "Gomphoid-phalloid group. Order presently unresolved. 1, limited to the wet tropics."

Acknowledgements. Rosa Gago helped us in preparing the illustrations. The 2009 stay in Singapore of V. Demoulin was made possible by a grant for sabbatical year of the Belgian Science Foundation (FNRS, now FRS). L. Cornet is supported by 'Fonds pour la Formation à la Recherche dans l'Industrie et dans l'Agriculture' (FRIA). D. Baurain is the recipient of a 'Starting grant' from the 'Fonds Spéciaux pour la Recherche' of the University of Liège (SFRD-12/04).

\section{REFERENCES}

Ainsworth G.C., Bisby G.R. 1954. A Dictionary of the Fungi. 4th Edition. The Commonwealth Mycological Institute, Kew.

Ainsworth G.C., James P.W., Hawksworth D.L. 1971. Ainsworth \& Bisby's Dictionary of the Fungi. 6th Edition. C.A.B., Commonwealth Mycological Institute, Kew.

Altschul S.F. et al. 1997. Gapped BLAST and PSI-BLAST: a new generation of protein database search programs. Nucleic Acids Res. 25: 3389-3402.

Benson D.A. et al. 2013. GenBank. Nucleic Acids Res. 41: D36-42.

Castellano M.A., Beever R.E. 1994. Truffle-like Basidiomycotina of New Zealand: Gallacea, Hysterangium, Phallobata and Protubera. New Zealand J. Bot. 32: 305-328. http://dx.doi.org/10.1080\%2F002 8825X.1994.10410473

Castresana J. 2000. Selection of conserved blocks from multiple alignments for their use in phylogenetic analysis. Mol. Biol. Evol. 17: 540-552. http://dx.doi.org/10.1093\%2Foxfordjournals.molbev.a026334

Demoulin V., Dring D.M. 1975. Gasteromycetes of Kivu (Zaïre), Rwanda and Burundi. Bull. Jard. Bot. Nat. Belgique 45: 339-372.

Federhen S. 2012. The NCBI Taxonomy database. Nucleic Acids Res. 40: D136-D143.

Felsenstein J. 1985. Confidence limits on phylogenies: an approach using the bootstrap. Evolution 39: 783-791. http://dx.doi.org/10.2307\%2F2408678

Fischer E. 1886. Lycogalopsis solmsii, ein neuer Gastromycet. Ber. Deutschen Bot. Ges. 4: 192-197. 
Fischer E. 1933. Gastomyceteae. (In:) A. E. Engler (ed.). Die natürlichen Pflanzenfamilien, ed. 2, 7a. W. Engelmann, Leipzig.

Giachini A.J., Hosaka K., Nouhrac E., Spatafora J., Trappe J. 2010. Phylogenetic relationships of the Gomphales based on nuc-25S-rDNA, mit-12S-rDNA, and mit-atp6-DNA combined sequences. Fungal Biol. 114: 224-234. http://dx.doi.org/10.1016\%2Fj.funbio.2010.01.002

Guindon S. et al. 2010. New algorithms and methods to estimate maximum-likelihood phylogenies: assessing the performance of PhyML 3.0. Syst. Biol. 59: 307-321.

Hawksworth D.L. Sutton B.C., Ainsworth G.C. 1983. Ainsworth \& Bisby's Dictionary of the Fungi. 7th Edition. C.A.B., Commonwealth Mycological Institute, Kew.

Hawksworth D.L., Kirk P.M., Sutton B.C., Pegler D.N. 1995. Ainsworth \& Bisby's Dictionary of the Fungi. 8th Edition. C.A.B, International Mycological Institute, Egham.

Holmgren P.K., Holmgren N.H., Barnett L.C. 1990. Index Herbariorum. I: The Herbaria of the World. 8th Edition. New York Botanical Garden, Bronx, New York.

Hosaka K. 2005. Systematics, Phylogeny, and Biogeography of the Hysterangiales and Related Taxa (Phallomycetidae, Homobasidiomycetes). PhD, Oregon State University, Corvallis, Oregon.

Hosaka K. et al. 2007 ("2006"). Molecular phylogenetics of the gomphoid-phalloid fungi with an establishment of the new subclass Phallomycetidae and two new orders. Mycologia 98: 949-959.

Katoh K. et al. 2005. MAFFT version 5: improvement in accuracy of multiple sequence alignment. Nucleic Acids Res. 33: 511-518.

Kirk M.P., Cannon P.F., David J.C., Stalpers J.A. 2001. Ainsworth \& Bisby's Dictionary of the Fungi. 9th Edition. CAB International, Wallingford.

Kirk M.P., Cannon P.F., Minter D.W., Stalpers J.A. 2008. Ainsworth \& Bisby's Dictionary of the Fungi. 10th Edition. Wallingford: CABI.

Lanave C. et al. 1984. A new method for calculating evolutionary substitution rates. J. Mol. Evol. 20: 86-93.

Martin G.W. 1939. The genus "Lycogalopsis". Lilloa 4: 69-73.

Moncalvo J.M., Wang H.-H., Hseu R.-Sh. 1995. Phylogenetic relationships in Ganoderma inferred from the internal transcribed spacers and 25S ribosomal DNA sequences. Mycologia 87: 223-238. http://dx.doi.org/10.2307\%2F3760908

Patouillard N. 1902. Champignons de la Guadeloupe recueillis par le R. P. Duss (3ème série). Bull. Soc. Mycol. France 18: 171-186.

Philippe H. 1993. MUST, a computer package of Management Utilities for Sequences and Trees. Nucleic Acids Res. 21: 5264-5272.

Quast C. et al. 2013. The SILVA ribosomal RNA gene database project: improved data processing and web-based tools. Nucleic Acids Res. 41: 590-596.

Smith J., Blanchette R.A., Newcombe E. 2004. Molecular and morphological characterization of the willow rust fungus, Melampsora epitea from arctic and temperate hosts in North America. Mycologia 96: 1330-1338. http://dx.doi.org/10.2307\%2F3762149

Vilgalys R., Hester M. 1990. Rapid genetic identification and mapping of enzymatically amplified ribosomal DNA from several Cryptococcus species. J. Bact. 172: 4238-4246.

Yang Z. 1993. Maximum-likelihood estimation of phylogeny from DNA sequences when substitution rates differ over sites. Mol. Biol. Evol. 10: 1396-1401. 